\title{
Thomas Mann's The Magic Mountain (1924): A questioning of health, rationality, and the romantic tradition
}

\section{Krzysztof Kosecki}

University of Łódź, Poland

\begin{abstract}
Thomas Mann's (1875-1955) epic novel The Magic Mountain (1924/1996) turns upside down the conventional axiology of the experiential categories of health and rationality, as well as of the romantic idea of a Bildungsreise or educational journey. The complex narrative describes a profound personal change of the main hero Hans Castorp, which takes place in opposition to the values of the conventional bourgeois society and against the background of the social and political condition of Europe on the verge of World War I.
\end{abstract}

Key words: axiology, health, illness, journey, love, rationality, Romantic, space.

\section{The author and his work}

The German writer Thomas Mann (1875-1955) grew up in Lübeck, in a wealthy Hanseatic family. In 1912 he spent some time in a sanatorium in the Swiss Alps, visiting his wife Katja, who was undergoing treatment for a lung disease. The writer learned on that occasion that he was prone to develop the disease himself (Łukowski, 1995, p. 663).

The complex novel The Magic Mountain (1924/1996) is partly patterned on Mann's personal experience. The main hero Hans Castorp, a young engineer studying for a career in shipbuilding, comes from a Hanseatic family based in Hamburg. He arrives in Davos to spend three weeks with his sick cousin Joachim Ziemssen, who is preparing for a military career. Having been diagnosed - like Mann himself - for potential tuberculosis, he decides to remain in Davos with the sick. The stay extends for seven years because Castorp falls in love with a mysterious Russian woman Clavdia Chauchat. At the same time he becomes confronted with two opposite worldviews - the Italian Lodovico Settembrini represents rational humanist liberalism; his opponent Naphta embodies the 
principles of authoritarianism and terror. Both these worldviews reflect the political conflicts current in Europe at the beginning of the $20^{\text {th }}$ century.

Castorp's long contact with the inhabitants of the Magic Mountain results in a profound personal change. By deciding not to the return to the flatlands, he rebels against his conventional middle class background and also questions the conventional senses of health and rationality. When the war breaks out in Europe, Castorp returns to the lowlands. As a result, his long educational journey does not come to a positive conclusion.

\section{Health, rationality, and axiology}

As two fundamental principles of human experience, health and illness do not lend themselves to straightforward interpretations. In a very general sense, a healthy organism correctly carries out all its functions, which leads to physical, social, and mental well-being (Godman \& Payne, 1981, p. 371). Illness is more than a disease, that is, various pathological factors and physical ailment accompanying them (Sontag, 1999). It also includes the reactions and attitudes of the individual and their social network to the condition, as well as cultural symbols and patterns of behaviour related to it (Kleinman, 1978 qtd. in Głowacki, 2009, pp. 123-124).

The fundamental opposition of health-illness overlaps with conventional axiological preferences. Most people want to be healthy and stay among the healthy rather than be sick and stay among the sick. Such conventional attitude is reflected in Castorp's response to Dr. Krokowski's inquiry on his arrival in Davos:

It was touching to see how Hans Castorp struggled to be polite and master his drowsiness. [...] he said something about three weeks, mentioned his exams, and added that, thank God, he was perfectly healthy. "You don't say!” Dr. Krokowski replied, thrusting his head forward at a derisive slant and smiling more broadly. "Then you are a phenomenon of greatest medical interest. You see, I've never met a perfectly healthy person before." (Mann, 1924/1996, p. 16)

As a physician, Dr. Krokowski voices the idea of the relativity of the concepts of health and illness. Mann, however, wholly inverts the conventional pattern of culture-based expectations. Though Castorp shows mild symptoms of disease, no ailment accompanies them as yet. As a result, his overall condition and behaviour show no signs of a full-fledged illness. Castorp, however, decides to stay in Davos. He subordinates himself to "the genius of illness" (Mann, 1924/1996, p. 602) and wants to be with other patients more seriously ill. The long stay among them has 
a positive effect on him - he discovers the world of higher ideas thorough the books that he reads and the conversations in which he engages. He also develops empathy and compassion for the sick, thus leaving his individualism and egotism behind.

Two conditions make human actions rational. First, according to the state of knowledge of the agent, their action must lead to desirable results. Secondly, the agent must also take into account the expectations about the behavior of other people in the environment, which serve as means to attain their ends (PenkalaGawęcka, 1998, pp. 120-121 qtd. in Głowacki, 2009, p. 121; Weber, 1922/1978). Castorp's decision to stay in sanatorium Berghof is irrational in that it does not lead to the completion of education in the flatlands and the start of professional activity related to it, which would be the expected course of action. It also goes against his conventional middle-class background, which was a factor stimulating the achievement. Castorp makes it clear to the Dutchman Mynheer Peppercorn, with whom Klavdia returns as a travelling companion:

I was not a military man myself, I have chosen a civilian profession, as you have perhaps heard, a sturdy, reasonable profession, of which it is even said that it may bring nations closer together, but of which I was never particularly fond, I must admit. As to the reasons, I can only say that they lie in darkness, lie there together with the origins of my sentiments toward your traveling companion [...] For the sake of her love and in spite of Herr Settembrini, I subordinated myself to the principle of irrationality, to the principle behind the genius of illness [...] I have forgotten everything, broken off with everything, with my relatives and my profession in the flatlands, with all my prospects [...] (Mann, 1924/1996, pp. 601-602).

Castorp thus gradually gives in to a life full of contemplative and intellectual experience, which stands in clear contrast to his predispositions and practical activity expected of him in the flatlands. The change takes place gradually:

[...] young Hans Castorp was caught up in a great many questions and distinctions - the sort that dear old Joachim did not think it was his duty to be concerned about, but for which, as a civilian, Hans Castorp had begun to feel a responsibility, even though down in the flatlands he had never noticed such questions, probably never would have noticed them, but certainly did here [...](Mann, 1924/1996, p. 383)

It was not the intended part of his visit in Davos, which was to last for the "rational" three weeks. For a contrast, Joachim longs for the flatlands, where he wants to pursue a military career that entails attending to rational and mundane duties. Hans's loss of interest in the flatlands is thus also the loss of interest in the conventional and mundane way of life there. Uncle James Tienappel, who 
visits Davos to persuade Hans to return to the flatlands and reassume rational action, quickly leaves Berghof without any success because Castrop is by then fully immersed in the way of life on the Magic Mountain.

The universal human tendency to perceive and categorize various aspects of experience "in terms of good-bad" is always correlated with the plus-minus nodes of the schema of scale (Wierzbicka, 1998, p. 210 qtd. in Krzeszowski, 1997, p. 226). Such parameters are "more or less explicitly present in every valuation" (Krzeszowski, 1993, p. 310; 1997, pp. 57-58, 109-111). In a typical context, health is evaluated as good and, as such, it is paired with the axiological plus node; illness, evaluated as bad, is paired with the minus node. Mann purposely turns the conventional scale upside down. Castorp says to Mynheer Pepperkorn: "[...] I subordinated myself [...] to the principle behind the genius of illness [...]" (Mann, 1924/1996, p. 601). Illness - because it facilitates his intellectual and spiritual growth - is regarded as good and is paired with the plus node of the axiological scale.

The plus-minus nodes of the axiological schema of scale also correspond to the respective nodes of space orientations, such as up-down, front-back, or centreperiphery, which arise directly from human experience (Johnson, 1987, p. xxxvi; Krzeszowski, 1997, p. 57). Mann pairs the plus-minus and the up-down nodes in the opposition of the Magic Mountain and the flatlands with the contrast of the intellectual and the mundane. The relation functions as the main structuring principle of the narrative. Because intellect is commonly regarded as positive, the plus node of the axiological schema is paired with the orientation 'up' represented by the Magic Mountain. However, intellect is also conventionally associated with rationality, and rationality is a major element of the culturally accepted pattern of human conduct, which has its roots in the classical culture and its dominant model of the Great Chain of Being (Lakoff \& Turner, 1989, pp. 166-169). In spite of it, Castorp regards his irrational behaviour as positive. The plus-minus nodes of the axiological schema of scale are thus inverted in this aspect of the narrative: the irrational is paired with the plus node and the orientation 'up' whereas the rational is paired with the minus node and the orientation 'down'. Rationality is also questioned by the inversion of the spatial opposition of centre-periphery. In a conventional axiology, central is regarded as positive and important; peripheral is regarded as negative and unimportant (Krzeszowski, 1993, p. 312; 1997, pp. 121-123). Hamburg, to which Castorp should have returned if he had acted rationally, is much more central in the social, economic, and political sense than Davos, located on the peripheries of the German-speaking world: "It is a long trip [...] from Hamburg to those elevations" (Mann, 1924/1996, p. 3). From Castorp's perspective, however, important and positive things happen in Davos; unimportant and negative things happen in the flatlands. 
Thomas Mann's The Magic Mountain (1924): A questioning of health, rationality...

That Mann decided to set his novel in a sanatorium located in the Swiss Alps may not be accidental. In an influential essay titled "Germany and the Germans", he explains:

A trip out of the Reich, say across Lake Constance, into Switzerland, was a trip out of the provincial into the world, - no matter how strange it may appear to regard the tiny country of Switzerland as "world" in comparison to the large and powerful German Reich with its gigantic cities. Still it was perfectly true: Switzerland, neutral, multilingual, under French influence, breathing western air, - notwithstanding its miniature format - was actually far more European, far more "World" than the political colossus to the north [...] (Mann, 1945, p. 3)

Berghof, which treats people from various countries of the world, is also "multilingual" and cosmopolitan. It is there rather than in the predominantly German and much less cosmopolitan flatlands that Hans Castorp comes into contact with diverse intellectual and political ideas.

As Castorp returns to the flatlands where the war breaks out, the inverted patterns assume their regular orientations. The brutality of the irrational war in which he participates is an antithesis to the sublime intellectual experience on the Magic Mountain. Though in a new form, the non-intellectual is still paired with the orientation 'down'; however, the irrational is now also connected with the conventional minus node and the orientation 'down'. The social and political centre - the flatlands - reassumes its importance; the little and peaceful Switzerland again becomes peripheral and unimportant. The centre, however, is still negative and the peripheries are still positive.

\section{The romantic tradition}

Romantic nature is more than a landscape that provides the background for human actions. It often acts as a stimulus for meditation of a solitary subject "concerned with central human experiences and problems" (Abrams, 1999, p. 178). The subject usually defies "common consciousness [...] sentiments and thoughts", as well as other standards of the conventional society (Grierson, 1962, p. 229; Harding, 1983, pp. 42-43). No longer "controlled by the social consciousness which checks eccentricity" (Grierson, 1962, p. 230), the solitary individual becomes a non-conformist or even a social outcast (Abrams, 1999, pp. 178179). He often engages in a quest for self-realization which takes the form of exzentrische Bahn 'eccentric way'. On such journey he experiences the division of 
the mind. The fragmentation is countered by "love" acting as a cohesive force and a unifying factor of human existence (Abrams, 1973, pp. 292-294; 1999, p. 178). The journey ends in the return to where the subject had started and culminates in him having the imagination augmented (Abrams, 1973, pp. 237-238, 255-256, 293-294).

In Mann's novel, the high altitudes and nature of the Swiss Alps are more than just the background for the events. Castorp stays in the place

where one looked down on the world and its creatures from the contemplative retreat of five thousand feet and thought one's thoughts, even if they were probably the result of enhanced activity of the body, which was caused by soluble toxins and made your face burn with a dry flush. (Mann, 1924/1996, p. 383)

He becomes concerned with questions and ideas more complex and profound than those with which he was occupied in the flatlands. His quest for self-realization takes on a more dramatic form when he is confronted with the political views of Settembrini and Naphta. As a result, Castorp experiences the division of the mind, but does not succumb to either of the influences. He falls in love with Klavdia Chauchat and - as a result - remains on the Magic Mountain for seven years "for the sake of her love, and in spite of Herr Settembrini" (Mann, 1924/1996, p. 601). His feelings and individual judgement now matter more than a bourgeois life governed by family rules, customs, values, and education directed at a practical career of an engineer.

Castorp thus becomes a middle-class non-conformist. Like other German Romantic heroes, for example Friedrich Hölderlin's (1770-1843) Hyperion (1797-1799), Johann W. von Goethe's (1749-1832) Faust (1833), or the heroes of Novalis's (1772-1801) The Novices of Sais (1802) and Henry von Ofterdingen (1802) (Abrams, 1973, pp. 237-252), Castorp goes on a circuitous journey, which represents human education in the individual and the collective sense. Though love for Klavdia to some extent counteracts the "fragmentation" that he experiences being exposed to two opposite ideologies, the final outcome of the "eccentric" journey is negative. He returns to where he had started because the war breaks out. The romantic outcast again becomes a social conformist. Because he is forced to assume the values that stand in a dramatic contrast to those experienced on the Magic Mountain, his imagination is not augmented. The effect of self-realization that he has experienced is thus likely to be lost:

Farewell, Hans - whether you live or stay where you are. [...] Adventures in the flesh and spirit, which enhanced and heightened your ordinariness, allowed you to survive 
Thomas Mann's The Magic Mountain (1924): A questioning of health, rationality...

in the spirit what you probably will not survive in the flesh. (Mann, 1924/1996, p. 706).

Castorp's love for Klavdia thus loses its unifying force. But the war in Europe is also an antithesis to a more general sense of love:

There were moments [...] when you saw the intimation of a dream of love rising up out of death and this carnal body. And out of this worldwide festival of death [...] will love someday rise up out of this, too? (Mann, 1924/1996, p. 706).

The negative outcome of Castrop's personal love for Klavdia now translates onto the overall condition of Europe.That is why Mann's epic novel can be read as a denial of the romantic Bildungsroman.

\section{References}

Abrams, M. H. (1973). Natural Supernaturalism: Tradition and Revolution in Romantic Literature. New York: Norton \& Norton.

Abrams, M. H. (1999). A Glossary of Literary Terms. Boston: Heinle \& Heinle.

Głowacki, A. (2009). Choroba - próba definicji [Illness - A Definition]. Barbarzyńca [Barbarian] 3-4(16-17), 113-129.

Godman, A., \& Payne, E. M. F. (1981). Longman Dictionary of Scientific Usage. Burnt Hill, UK: Longman Group.

Goethe, J. W. von (1974). Faust, Parts 1 and 2 (B. Taylor, Trans.). London: Sphere. (Original work published 1833).

Grierson, H. J. C. (1962). Classical and romantic: A point of view. In The Background of English Literature, (pp. 221-249). Harmondsworth, England: Penguin Books. (Original work published 1925).

Harding, D. W. (1983). The character of literature from Blake to Byron. In B. Ford (ed.), The New Pelican Guide to English Literature, vol. 5: From Blake to Byron, (pp. 35-66). Harmondsworth, England: Penguin Books.

Hölderlin, F. (1965). Hyperion (W. R. Trask, Trans.). New York: Signet Books. (Original work published 1797-1799).

Johnson, M. (1987). The Body in the Mind: The Bodily Basis of Meaning, Imagination, and Reason. Chicago: University of Chicago Press.

Kleinman, A. 1978. Concepts and model for the comparison of medical systems as cultural systems. Social Science and Medicine, 12, 85-93.

Krzeszowski, T. P. (1993). The axiological parameter in preconceptual image schemata. In R. A. Geiger \& B. Rudzka-Ostyn (eds.), Conceptualisations and Mental Processing in Language, (pp. 307-329). Berlin: Mouton de Gruyter.

Krzeszowski, T. P. (1997). Angels and Devils in Hell: Elements of Axiology in Semantics. Warsaw, Poland: Wydawnictwo Energeia. 
Lakoff, G., \& Turner, M. (1989). More Than Cool Reason: A Field Guide to Poetic Metaphor. Chicago: University of Chicago Press.

Łukowski, J. (1995). Posłowie [Epilogue]. In T. Mann, Czarodziejska góra [The Magic Mountain] (J. Łukowski \& J. Kramsztyk, Trans., pp. 661-667). Wrocław, Poland: Wydawnictwo Dolnośląskie.

Mann, T. (1996). The Magic Mountain (J. E. Woods, Trans.). New York: Vintage Press. (Original work published 1924).

Mann, T. (1945). Germany and the Germans. Washington: Library of Congress. Retrieved from Hathi Trust Digital Library at htops://catalog.hathitrust.org/Record/006168882 on 25 October, 2018.

Novalis (2005). The Novices of Sais (R. Manheim, Trans.). New York: Archipelago Books. (Original work published 1798-1799).

Novalis (1964). Henry von Ofterdingen (P. Hilty, Trans.). New York: Frederick Ungar Publishing. (Original work published 1799-1800).

Penkala-Gawęcka, D. (1998). Badania etnologiczne nad medycyną komplementarną [Ethnological study on complementary medicine]. In M. Libiszowska-Żółtkowska, M. OgryzkoWiewiórowska, \& W. Piątkowski (eds.), Szkice z socjologii medycyny [Studies n Sociological Medicine], (pp. 117-125). Lublin: Wydawnictwo Uniwersytetu Marii Curie-Skłodowskiej.

Sontag, S. (1999). Choroba jako metafora [Illness as Metaphor] (J. Anders, Trans.). Warszawa: Państwowy Instytut Wydawniczy.

Weber, M. (1978). Economy and Society: An Outline of Interpretive Sociology. Berkeley, CA: University of California Press. (Original work published 1922).

Wierzbicka, A. (1988). The Semantics of Grammar. Amsterdam: John Benjamins Publishing Corporation. 